\title{
Effects of Once Versus Twice Daily Milking Throughout Lactation on Milk Yield and Milk Composition in Dairy Goats
}

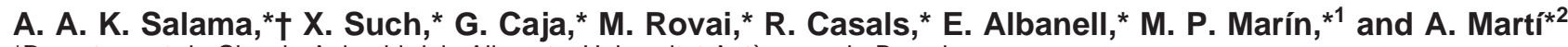 \\ ${ }^{*}$ Departament de Ciencia Animal i dels Aliments, Universitat Autònoma de Barcelona, \\ 08193 Bellaterra, Spain \\ †Sheep and Goat Research Department, Animal Production Research Institute, 4 Nadi El-Said St., \\ 12311 Dokki, Giza, Egypt
}

\begin{abstract}
The effects of once (1X) vs. twice (2X) daily milking throughout lactation on milk yield, milk composition, somatic cell count (SCC), and udder health were studied in 32 Murciano-Granadina dairy goats. Goats were assigned at wk 2 of lactation to two treatment groups; once daily milking at $0900(1 \mathrm{X}, \mathrm{n}=17)$, or twice daily milking at 0900 and $1700(2 \mathrm{X}, \mathrm{n}=15)$. Milk yield was recorded weekly until wk 28 , and milk composition and SCC were evaluated for each individual udder half at each milking at wk 2 and 4 of lactation and then, monthly until the end of the experiment. Once daily milking resulted in an $18 \%$ reduction in the yield of $4 \%$ fat-corrected milk compared to twice daily milking (1.61 vs. $1.95 \mathrm{~L} / \mathrm{d}$, respectively). This reduction was more marked from wk 2 to 12 than in mid and late lactation. Response to milking frequency also varied according to parity number where goats of less than four parities suffered more milk yield losses during $1 \mathrm{X}$ than older goats. Milk of $1 \mathrm{X}$ goats contained higher percentages of total solids (13.6 vs. $12.9 \%)$, fat (5.10 vs. $4.62 \%$ ) and casein ( 2.57 vs. $2.35 \%$ ) than milk of $2 \mathrm{X}$ goats, but milk protein percentage did not differ between treatments (3.28 vs. $3.20 \%$ ). Yields of total solids, fat, protein and casein tended to be higher for $2 \mathrm{X}$ than $1 \mathrm{X}$. Milk SCC did not differ between treatments. We conclude that application of once daily milking in Murciano-Granadina dairy goats moderately reduced milk yield without negative effects on milk composition and udder health. Losses in milk yield would be reduced if $1 \mathrm{X}$ is practiced during mid- or late lactation and in older goats. An increase in labor productivity and a higher farmer's standard of living is also expected.
\end{abstract}

Received August 23, 2002.

Accepted October 23, 2002

Corresponding author: G. Caja; e-mail: gerardo.caja@uab.es.

${ }^{1}$ Present address: Universidad de Santo Tomás, Santiago de Chile, Chile.

${ }^{2}$ Present address: Departamento de Tecnología Agroalimentaria, Universidad Miguel Hernández de Elche, 03312 Orihuela, Spain.
(Key words: once daily milking, milk production, somatic cell count, dairy goat)

Abbreviation key: $\mathbf{1 X}=$ once daily milking, $\mathbf{2 X}=$ twice daily milking, FIL = feedback inhibitor of lactation, $\mathbf{T} \mathbf{J}$ $=$ tight junction.

\section{INTRODUCTION}

Number of daily milkings is of great importance in determining milk yield in dairy animals. Once daily milking of dairy cows is practiced in some countries either in early lactation to reduce metabolic stress or in late lactation to improve quality of farming life (Davis et al., 1999). Compared with twice daily milking (2X), once daily milking (1X) reduced milk yield by 7 to $38 \%$ in dairy cows (Stelwagen et al., 1994a; Stelwagen and Knight, 1997), 15 to $48 \%$ in ewes (Knight et al., 1993; Negrao et al., 2001) and 6 to 35\% in dairy goats (Mocquot, 1978; Capote et al., 1999). The wide variation in yield losses during $1 \mathrm{X}$ reported by other authors may be due to differences in breed, lactation stage, level of production, duration of $1 \mathrm{X}$ milking and individual characteristics.

Bewly et al. (2001) reported that more frequent milking requires more variable costs (labor, utilities, milking supplies, and additional feed costs). In Spain, and other countries where the goat production systems are extensive or semi-extensive, high milking frequency is a major cost for dairy goat farms. Under these conditions, lower milking frequency increases labor productivity and reduces milk storage risks. However, for infrequent milking to be a practical strategy, it should have no long-term deleterious effects on milk yield or milk quality.

Somatic cell count in goat milk has become an important quality index since goat milk was officially defined in the grade A Pasteurized Milk Ordinance in 1989 in the USA (Zeng and Escobar, 1995), and a European regulation (92/46 EEC) to control SCC in goat milk was issued in 1992. Moreover, the relatively low cost and rapidity of SCC determination have resulted in it being widely used as an indicator of milk quality 
and as a management tool to determine the prevalence of IMI in dairy animals. It is well established that SCC in dairy goats is affected by IMI (Zeng and Escobar, 1995), parity number (Sánchez et al., 1999), stage of lactation (Wilson et al., 1995), breed (Sung et al., 1999), level of milk production (Hinckley, 1983), nutritional status and milking method (Salama et al., 2003), and estrus (McDougall and Voermans, 2002). However, there is no information on the effect of milking frequency on SCC in dairy goats.

The objectives of this study were to investigate the effects in lactating Murciano-Granadina goats of $1 \mathrm{X}$ vs. $2 \mathrm{X}$ throughout lactation on: 1) milk yield and chemical composition, 2) milk SCC and udder health, and 3) secretion of milk and its components at different milking intervals.

\section{MATERIALS AND METHODS}

\section{Animals and Management Conditions}

Two milking frequencies were studied over 2 consecutive years in a total of 32 Murciano-Granadina dairy goats (17 and 15 goats for the first and second yr, respectively) from the herd of the experimental farm of the S1GCE (Servei de Granges i Camps Experimentals) of the Universitat Autonoma of Barcelona. Goats were divided into two groups and milked from parturition to wk 42 of lactation, when they were dried off. Kids were separated from their dams within $8 \mathrm{~h}$ of birth and reared on milk substitutes and all goats were milked twice daily until wk 2 . In both years, groups were balanced with respect to parity, milk yield and SCC; baseline measurements were recorded on two consecutive days in wk 2 of lactation. Goat parities were: first, 5; second, 9; third, 7; and, fourth or more, 11. Treatments were randomly applied to the groups from wk 2 to dryoff, and were: goats milked once daily at 0900 (1X; n = 9 and 8, for the first and second yr, respectively), and goats milked twice daily at 0900 and $1700(2 \mathrm{X} ; \mathrm{n}=8$ and 7 , for the first and second yr, respectively). New goats were used for both treatments in the 2 nd yr. Both groups grazed on natural pastures for $6 \mathrm{~h}$ daily and were supplemented with concentrate in the milking parlor (1.53 Mcal NE $/ \mathrm{kg}, 16 \% \mathrm{CP}$, as fed) at a flat rate of 0.5 to $1 \mathrm{~kg} /$ doe per day according to lactation stage, and with $0.5 \mathrm{~kg} / \mathrm{doe}$ alfalfa and $0.5 \mathrm{~kg} /$ doe alfalfa pellets in the shelter.

Goats were milked in a double-12 stall parallel milking parlor (Westfalia Landtechnik, Granollers, Spain) equipped with recording jars $(2 \mathrm{~L} \pm 5 \%)$ and low-line milk pipeline. Milking was performed at a vacuum pressure of $42 \mathrm{kPa}$, a pulsation rate of 90 pulses/min, and a pulsation ratio of $66 \%$ according to the milking parameters used in the breed (Peris et al., 1996). Milking routine included machine milking, machine stripping before cluster removal, and teat dipping in an iodine solution (P3-cide plus, Henkel Hygiene, Barcelona, Spain).

\section{Sample Collection, Analysis, and Measurements}

Milk recording and sampling were done from wk 2 to 28 of lactation. Milk yield of individual goats was recorded weekly at every milking by using the recording jars in the milking parlor. Milk samples were taken from each udder half after each milking for analysis of composition, SCC and bacteriology at wk 2 and 4 of lactation and then monthly until wk 28 . Milk yield was also recorded by udder half on the sampling days. Yield of FCM in 300 DIM was estimated according to Thomas et al. (2000).

Milk yield and milk composition recording at each milking (a.m. and p.m.) allowed the study of the secretion of milk and milk components during the different periods of milk accumulation ( 8 and $16 \mathrm{~h}$ for $2 \mathrm{X}$ goats, and $24 \mathrm{~h}$ for $1 \mathrm{X}$ goats).

For analysis of milk composition, a sample of approximately $100 \mathrm{ml}$ was collected and preserved with $\mathrm{K}_{2} \mathrm{Cr}_{2} \mathrm{O}_{7}(0.3 \mathrm{~g} / \mathrm{L})$ at $4^{\circ} \mathrm{C}$. Unhomogenized milk samples were analyzed with a near infrared spectrometer (Technicon InfraAlyzer- 450, Bran+Luebbe SL, Nordersted, Germany), using the method of Albanell et al. (1999), for content of TS, fat, $\mathrm{CP}(\mathrm{N} \times 6.38)$, and $\mathrm{CN}$.

For SCC, a sample of approximately $50 \mathrm{ml}$ was placed in a plastic vial, preserved with an anti-microbial tablet (Bronopol, Broad Spectrum Micro-tabs II, D\&F Control Systems Inc., San Ramon, CA) and kept at $4^{\circ} \mathrm{C}$ until analysis. The SCC was determined in the Dairy Herd Improvement laboratory of Catalonia (Allic, Cabrils, Barcelona, Spain) using an automatic cell counter (Fossomatic 250, Foss-Electric, Hillerød, Denmark). Routine bacteriological culture was performed on aseptic milk samples obtained from each udder half before milking. An infection was assumed to have occurred if five or more similar cfu were present in the incubated sample of milk.

\section{Statistical Analysis}

Data from one goat in each treatment were excluded from the statistical analysis because of an IMI. Data were analyzed by the PROC MIXED for repeated measurements of SAS (SAS 8.1; SAS Inst. Inc., Cary, NC). The statistical mixed model included the fixed effects of milking frequency, year, parity, prolificacy, and wk of lactation; the random effects of the animal and half udder nested within animal; and the interactions of milking frequency to the factors of year, parity, and wk 
of lactation; and the residual effect. Random effect of udder half nested within animal was excluded from the model in the analysis of milk yield. For data analysis of milk secretion during different milking intervals, the fixed effect of milking frequency was replaced by the fixed effect of milking interval ( 8 and $16 \mathrm{~h}$ corresponded to $2 \mathrm{X}$ goats and $24 \mathrm{~h}$ corresponded to $1 \mathrm{X}$ goats). Parity number was grouped into three categories corresponding to first and second parities $(\mathrm{n}=14)$, third parity ( $\mathrm{n}$ $=7$ ), and fourth or more parities $(n=9)$. Goats of first and second parities were grouped together because they had in many cases the same age. The prolificacy effect corresponded to two levels defined as single or multiple kids. Logarithmic transformations $\left(\log _{10}\right)$ of SCC values were used in statistical analysis. Data from wk 2 were used as a covariate to correct for differences in initial values when necessary. Significance was declared as $P$ $<0.05$ unless otherwise indicated.

\section{RESULTS AND DISCUSSION}

\section{Milk Yield}

Year significantly affected FCM yield throughout lactation and milk yield during midlactation (wk 13 to 28), but interaction between yr and treatment was not significant.

As shown in Table 1 and Figure 1, $1 \mathrm{X}$ resulted in a $18 \%$ significant reduction in FCM daily yield compared to $2 \mathrm{X}(-0.34 \mathrm{~L} / \mathrm{d})$ during the experimental period. This reduction was greater than the values previously reported in Canarian goats (6\%) by Capote et al. (1999) but smaller than in Alpine goats (36\%) by Mocquot (1978) for overall lactation. Moreover, Wilde and Knight (1990) reported a loss of $26 \%$ in Saanen goats in a shortterm experiment in early lactation, while losses ranged between 6 and 7\% in Damascus goats during middle and late lactation, respectively (Papachristoforou et al., 1982). The increase in the concentration of the putative feedback inhibitor of lactation (FIL), synthesized by the mammary gland (Wilde et al., 1995) and the intramammary pressure (Peaker, 1980) may cause the decrease in milk synthesis in $1 \mathrm{X}$ goats. Also, the loss of tight junction (TJ) integrity after about $20 \mathrm{~h}$ of milk accumulation may play a role in the milk yield losses in 1X (Stelwagen et al., 1994b). When less frequent milking is prolonged, the decrease in milk yield is sustained by sequential developmental adaptations, initially as a down-regulation of cellular differentiation (Wilde et al., 1987) and later as a net loss in mammary cell number via apoptosis ( $\mathrm{Li}$ et al., 1999).

The reduction in $4 \% \mathrm{FCM}$ yield due to $1 \mathrm{X}$ was more marked during the first 3 mo of lactation (19\%) than in late lactation $(14 \% ; P<0.08)$. In accordance, Stelwagen and Knight (1997) reported that milk yield losses
Table 1. Effect of milking frequency on milk yield, chemical composition, and somatic cell count in dairy goats. ${ }^{1}$

\begin{tabular}{|c|c|c|c|}
\hline \multirow[b]{2}{*}{ Dependent variable } & \multicolumn{2}{|c|}{ Milking frequency $^{2}$} & \multirow[b]{2}{*}{ SED } \\
\hline & $\begin{array}{l}1 \mathrm{X} \\
(\mathrm{n}=16)\end{array}$ & $\begin{array}{l}2 \mathrm{X} \\
(\mathrm{n}=14)\end{array}$ & \\
\hline \multicolumn{4}{|l|}{ Milk yield } \\
\hline wk 2 to $12, \mathrm{~L} / \mathrm{d}$ & $1.50^{\mathrm{b}}$ & $1.89^{\mathrm{a}}$ & 0.16 \\
\hline wk 13 to $28, \mathrm{~L} / \mathrm{d}$ & $1.34^{\mathrm{b}}$ & $1.61^{\mathrm{a}}$ & 0.20 \\
\hline wk 2 to $28, \mathrm{~L} / \mathrm{d}$ & $1.43^{\mathrm{b}}$ & $1.76^{\mathrm{a}}$ & 0.19 \\
\hline Estimated 300 DIM, L & $460^{\mathrm{b}}$ & $531^{\mathrm{a}}$ & 31 \\
\hline $\mathrm{FCM}^{3}$ & & & \\
\hline wk 2 to $12, \mathrm{~L} / \mathrm{d}$ & $1.70^{\mathrm{b}}$ & $2.09^{\mathrm{a}}$ & 0.17 \\
\hline wk 13 to $28, \mathrm{~L} / \mathrm{d}$ & 1.55 & 1.81 & 0.17 \\
\hline wk 2 to $28, \mathrm{~L} / \mathrm{d}$ & $1.61^{\mathrm{b}}$ & $1.95^{\mathrm{a}}$ & 0.15 \\
\hline Estimated 300 DIM, L & $504^{\mathrm{b}}$ & $590^{\mathrm{a}}$ & 28 \\
\hline \multicolumn{4}{|l|}{ Milk components } \\
\hline Total solids, \% & $13.6^{\mathrm{a}}$ & $12.9^{\mathrm{b}}$ & 0.2 \\
\hline Total solids, g/d & $198.0^{\mathrm{b}}$ & $225.8^{\mathrm{a}}$ & 20.5 \\
\hline Fat, $\%$ & $5.10^{\mathrm{a}}$ & $4.62^{\mathrm{b}}$ & 0.21 \\
\hline Fat, g/d & 69.1 & 81.0 & 7.1 \\
\hline Protein, \% & 3.28 & 3.20 & 0.08 \\
\hline Protein, g/d & 45.2 & 54.4 & 5.3 \\
\hline Casein, \% & $2.57^{\mathrm{a}}$ & $2.35^{\mathrm{b}}$ & 0.07 \\
\hline Casein, g/d & 33.8 & 40.6 & 4.1 \\
\hline $\mathrm{SCC}, \log _{10} / \mathrm{ml}$ & 5.95 & 5.86 & 0.07 \\
\hline $\mathrm{SCC}, \log _{10} / \mathrm{d}$ & 8.77 & 8.76 & 0.07 \\
\hline
\end{tabular}

${ }^{1}$ Data are least square means and standard errors of the difference $(\mathrm{n}=30)$.

${ }^{2}$ Once (1X) or twice (2X) daily milking.

${ }^{3} 4 \% \mathrm{FCM}=0.4$ (L of milk) +15 (kg of fat).

a,b Means with different superscripts within the same row are different $(P<0.05)$.

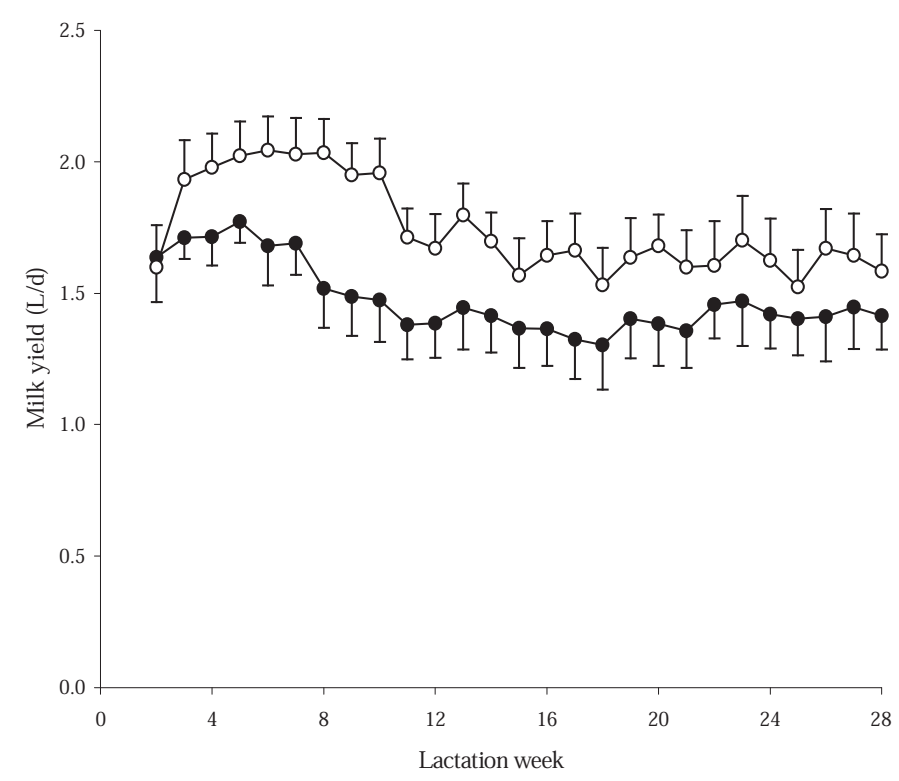

Figure 1. Milk production of dairy goats milked once $(\mathbf{n}=16)$ or twice $(O ; \mathrm{n}=14)$ daily. Values are means with SEM indicated by vertical bars. 
Table 2. Effect of milking frequency according to parity number on fat corrected milk yield, chemical composition, and somatic cell count in dairy goats. ${ }^{1}$

\begin{tabular}{|c|c|c|c|c|}
\hline \multirow[b]{2}{*}{ Dependent variable } & \multirow[b]{2}{*}{ Parity category ${ }^{3}$} & \multicolumn{2}{|c|}{ Milking frequency $^{2}$} & \multirow[b]{2}{*}{ SED } \\
\hline & & $1 \mathrm{X}$ & $2 \mathrm{X}$ & \\
\hline \multirow[t]{3}{*}{$\mathrm{FCM}^{4}, \mathrm{~L} / \mathrm{d}$} & 1 & $1.52^{\mathrm{b}}$ & $2.43^{\mathrm{a}}$ & 0.220 \\
\hline & 2 & $1.38^{\mathrm{b}}$ & $1.79^{\mathrm{a}}$ & 0.210 \\
\hline & 3 & 1.68 & 1.87 & 0.172 \\
\hline \multirow[t]{3}{*}{ Milk total solids, \% } & 1 & $13.46^{\mathrm{a}}$ & $12.36^{\mathrm{b}}$ & 0.301 \\
\hline & 2 & $14.08^{\mathrm{a}}$ & $13.45^{\mathrm{b}}$ & 0.311 \\
\hline & 3 & 13.52 & 13.01 & 0.264 \\
\hline \multirow[t]{3}{*}{ Milk fat, $\%$} & 1 & $5.33^{\mathrm{a}}$ & $3.95^{\mathrm{b}}$ & 0.286 \\
\hline & 2 & 5.72 & 5.20 & 0.282 \\
\hline & 3 & 5.15 & 4.81 & 0.243 \\
\hline \multirow[t]{3}{*}{ Milk protein, \% } & 1 & 3.22 & 3.14 & 0.090 \\
\hline & 2 & 3.36 & 3.27 & 0.094 \\
\hline & 3 & $3.40^{\mathrm{a}}$ & $3.15^{\mathrm{b}}$ & 0.078 \\
\hline \multirow[t]{3}{*}{ Milk casein, \% } & 1 & 2.39 & 2.40 & 0.086 \\
\hline & 2 & $2.59^{\mathrm{a}}$ & $2.25^{\mathrm{b}}$ & 0.084 \\
\hline & 3 & $2.75^{\mathrm{a}}$ & $2.38^{\mathrm{b}}$ & 0.072 \\
\hline \multirow[t]{3}{*}{ Milk SCC, $\log _{10} / \mathrm{ml}$} & 1 & 5.47 & 5.31 & 0.175 \\
\hline & 2 & 5.87 & 5.86 & 0.077 \\
\hline & 3 & 6.51 & 6.38 & 0.112 \\
\hline \multirow{2}{*}{\multicolumn{5}{|c|}{$\begin{array}{l}{ }^{1} \text { Data are least square means and standard errors of the difference }(n=30) \text {. } \\
{ }^{2} \text { Once }(1 \mathrm{X}) \text { or twice }(2 \mathrm{X}) \text { daily milking. }\end{array}$}} \\
\hline & & & & ${ }^{2}$ Once (1X) or twice (2X) daily milking. \\
\hline \multicolumn{5}{|c|}{$\begin{array}{l}\left.{ }^{\circ} \text { Parity number was grouped into } 3 \text { categories: } 1 \text { (1st and } 2 \mathrm{nd}, \mathrm{n}=14\right), 2(3 \mathrm{rd}, \mathrm{n}=7) \text {, and } 3(4 \text { th or more, } \\
\mathrm{n}=9 \text { ). }\end{array}$} \\
\hline
\end{tabular}

in dairy cow during $1 \mathrm{X}$ in late lactation were lower than in early lactation. McKusick et al. (2002) reported no differences in milk yield between milking every $16 \mathrm{~h}$ compared with every $12 \mathrm{~h}$ during mid- to late-lactation in dairy ewes, but milk yield was reduced after more than $16 \mathrm{~h}$ of milk accumulation in a short term experiment conducted in the same flock.

Mammary gland cisternal capacity appears to be a constraint in cows milked 1X (Knight and Dewhurst, 1994) and cisternal milk proportion increases during the course of a normal lactation in cows (Dewhurst and Knight, 1993) and in dairy ewes (Rovai et al., 2002). Our data also suggest that the cisternal capacity is critical in dairy goats during early lactation when higher levels of milk are produced, while in late lactation (descending phase), the cisterns may have been able to better accommodate the level of milk production, resulting in lesser effect of FIL, and thus lower milk yield losses as previously indicated in Canarian goats that have large cisterns (Capote et al., 1999).

The reduction in FCM yield during $1 \mathrm{X}$ varied also according to parity number: $38 \%$ in first and second parities, $22 \%$ in third parity, and $11 \%$ in more than third parity (Table 2). Primiparous cows are reported to have a proportionately greater response to increased milking frequency than multiparous cows (DePeters et al., 1985). As parity number increased, cistern capacity increased in cows (Dewhurst and Knight, 1993) and dairy ewes (Rovai et al., 2002). Increased cistern capacity might reduce the negative effect of FIL on milk secretion when milk accumulates in the alveoli, thereby decreasing the positive response to $2 \mathrm{X}$ in older animals. Positive correlations between milk yield and proportion or volume of cisternal milk in dairy cows milked $1 \mathrm{X}$ were reported (Stelwagen and Knight, 1997).

There is no documentation on the effects of $1 \mathrm{X}$ on lactation persistency in dairy goats. Both $1 \mathrm{X}$ and $2 \mathrm{X}$ groups had a maximum yield of $1.75 \pm 0.13$ and $2.00 \pm$ $0.10 \mathrm{~L}(P<0.01)$ during wk 4 and 5 of lactation, respectively (Figure 1). Persistency of lactation as defined recently by Grossman et al. (1999) is the number of days during which the level of peak yield is maintained. Applying this definition, $1 \mathrm{X}$ goats persisted for $21 \pm 3$ $\mathrm{d}$, which was lower $(P<0.01)$ than in $2 \mathrm{X}$ goats $(40 \pm 5 \mathrm{~d})$. By the end of the study (196 DIM), goats were producing approximately 83 and $79 \%$ of their peak production for $1 \mathrm{X}$ and 2X, respectively, which was higher than the $30 \%$ recorded by dairy cows at a similar stage of lactation (Lacy-Hulbert et al., 1999). Milking frequency did not affect lactation length in any of the studied treatments and all goats in this experiment were dried-off routinely for 300 DIM on average. Total $4 \%$ FCM for 300 DIM was $14.6 \%$ lower for $1 \mathrm{X}$ than for $2 \mathrm{X}$ (Table 1 ). Dairy ewes milked every $12 \mathrm{~h}$ had similar lactation length and milk yield than did ewes milked every $16 \mathrm{~h}$ (McKusick et al., 2002). 
We have to take into account that goats used in this study came from a herd initially bred under $2 \mathrm{X}$ milking conditions. The same herd is at present managed under $1 \mathrm{X}$ milking and the goats yielded more than $2.0 \mathrm{~L}$ of $4 \%$ FCM daily (González et al., 2002; Salama et al., 2003 ), which is similar to the production of $2 \mathrm{X}$ goats in this experiment. Indeed, the possibility exists that during breeding under $1 \mathrm{X}$ milking conditions goats may become more tolerant and adapted to less frequent milking and, consequently, losses in milk yield for $1 \mathrm{X}$ would be reduced.

\section{Milk Composition}

Year significantly affected yield and percentage of milk components with the exception of protein percentage $(P=0.619)$ and $\mathrm{CN}$ percentage $(P=0.195)$. A tendency was also observed for $\mathrm{CN}$ yield $(P=0.096)$, but interaction between yr and treatment was not significant.

Milk of $1 \mathrm{X}$ goats was more concentrated than milk of $2 \mathrm{X}$ goats and had higher concentrations of TS $(+6 \%)$, fat $(+10 \%)$ and $\mathrm{CN}(+9 \%)$, as indicated in Table 1 . This could be expected as a consequence of the concentration of milk components when milk yield decreased as well as a result of changes occurred in the synthesis of milk components. In dairy cows, concentration of fat, protein and $\mathrm{CN}$ increased as a result of $1 \mathrm{X}$ for short periods at late lactation (Lacy-Hulbert et al., 1999) or during an entire lactation (Holmes et al., 1992). In contrast, as milking interval increased, milk fat content decreased while milk protein content increased in a short term experiment in dairy ewes in which oxytocin was used to remove alveolar milk (McKusick et al., 2002). The same authors observed that ewes milked every $12 \mathrm{~h}$ had similar milk production, milk fat and protein percentages and yields than did ewes milked every $16 \mathrm{~h}$, in a trial conducted during mid-lactation (McKusick et al., 2002). Changes in fat concentration in milk may be related to differing regulatory mechanisms for secretion of milk fat globules relative to the components in the aqueous phase of milk and to the transfer between alveolar and cisternal compartments (Davis et al., 1999; McKusick et al., 2002).

Percentage of milk protein did not vary significantly between treatment groups $(P=0.260)$ in our results, as reported in dairy ewes milked every $12 \mathrm{~h}$ vs. $16 \mathrm{~h}$ (McKusick et al., 2002). Total protein in milk is the result of the proteins synthesized in the mammary gland and the serum proteins entering the milk when mammary TJ are disrupted. Casein does not move through leaky mammary TJ, presumably because of the large size of their micelles (Stelwagen et al., 1998). Thus, while milk volume was lower with $1 \mathrm{X}, \mathrm{CN}$ synthe- sized remained and became more concentrated in the milk. Nevertheless, $1 \mathrm{X}$ milking is often associated with increased plasmin and plasminogen activities (Stelwagen et al., 1994c) which may lead to the breakdown of $\beta$-CN to $\gamma$-CN without changes in total CN. Moreover, mammals have the ability to provide milk that is consistent in protein concentration regardless of the most environmental stresses (Cowie and Tindal, 1971).

Daily yield of TS significantly decreased by $12 \%$ in $1 \mathrm{X}$ goats, and daily yields of fat $(P=0.073)$, protein $(P$ $=0.086)$ and $\mathrm{CN}(P=0.098)$ tended to be reduced by 15,17 and $16 \%$, respectively, in agreement with the significant reduction in the daily milk volume (19\%).

\section{Milk SCC and Udder Health}

SCC is an important index for milk quality and in many countries it is used as a criterion for milk payment to producers, penalizing goat milk that contains more than $1 \times 10^{6} \mathrm{cell} / \mathrm{s} / \mathrm{ml}$. However, there is no data on the effect of $1 \mathrm{X}$ on milk SCC in dairy goats. No significant effects were detected for yr or interaction between yr and treatment on milk SCC. Moreover, SCC did not differ $(P=0.190)$ between treatments (Table 1$)$ and the geometric means of SCC throughout lactation were 979 and $917 \times 10^{3}$ cells $/ \mathrm{ml}$ for $1 \mathrm{X}$ and $2 \mathrm{X}$, respectively. However, these values were greater than previously reported by Salama et al. (2003) in the same conditions.

Available information on SCC in cows during $1 \mathrm{X}$ is contradictory. In agreement with our results, both Stelwagen et al. (1994a) and Lacy-Hulbert et al. (1999) indicated no significant effect of $1 \mathrm{X}$ on milk SCC at late lactation. In contrast, milking dairy cows $1 \mathrm{X}$ throughout lactation (Holmes et al., 1992) or for short periods at early (Stelwagen and Lacy-Hulbert, 1996) or late (Kelly et al., 1998) lactation increased SCC. This increase may be due in part to a concentration effect as milk yield decreased during 1X (Kamote et al., 1994) and in part to the impairment of the TJ barrier facilitating a paracellular influx of somatic cells into the milk without damage to the mammary secretory cells (Stelwagen and Lacy-Hulbert, 1996). Kamote et al. (1994) suggested that if the initial SCC level is low, 1X results in a small increase in SCC. Goats in this experiment started lactation with relatively high SCC but SCC did not increase significantly during1X. Dairy ewes milked every $12 \mathrm{~h}$ had similar SCC in milk than did ewes milked every $16 \mathrm{~h}$ (McKusick et al., 2002).

Bacteriological culture revealed that one half udder of one goat in each treatment had an IMI. Clinical mastitis was not observed in any of the studied goats suggesting that $1 \mathrm{X}$ had no deleterious effect on udder health. Similarly, udders of dairy cows milked $1 \mathrm{X}$ throughout lactation did not suffer any mastitis problems, although milk 
Table 3. Secretion rate of milk and its components, and milk composition according to milking interval in dairy goats milked at different milking frequencies. ${ }^{1}$

\begin{tabular}{|c|c|c|c|c|}
\hline \multirow[b]{3}{*}{ Dependent variable } & \multicolumn{3}{|c|}{ Milking frequency $^{2}$} & \multirow{3}{*}{ SEM } \\
\hline & \multicolumn{2}{|c|}{$2 \mathrm{X}$} & \multirow{2}{*}{$\frac{1 \mathrm{X}}{24 \mathrm{~h}}$} & \\
\hline & $8 \mathrm{~h}$ & $16 \mathrm{~h}$ & & \\
\hline Milk, ml/h & $80^{\mathrm{a}}$ & $71^{\mathrm{b}}$ & $58^{\mathrm{c}}$ & 3 \\
\hline Milk fat, $\mathrm{g} / \mathrm{h}$ & $4.34^{\mathrm{a}}$ & $2.96^{\mathrm{b}}$ & $2.94^{\mathrm{b}}$ & 0.14 \\
\hline Milk fat, $\%$ & $5.43^{\mathrm{a}}$ & $4.14^{\mathrm{b}}$ & $5.11^{\mathrm{a}}$ & 0.21 \\
\hline Milk protein, g/h & $2.41^{\mathrm{a}}$ & $2.30^{\mathrm{a}}$ & $1.89^{\mathrm{b}}$ & 0.09 \\
\hline Milk protein, \% & $3.04^{\mathrm{b}}$ & $3.23^{\mathrm{a}}$ & $3.29^{\mathrm{a}}$ & 0.07 \\
\hline Milk casein, g/h & $1.81^{\mathrm{a}}$ & $1.64^{\mathrm{b}}$ & $1.48^{\mathrm{b}}$ & 0.06 \\
\hline Milk casein, \% & $2.26^{\mathrm{c}}$ & $2.33^{\mathrm{b}}$ & $2.56^{\mathrm{a}}$ & 0.05 \\
\hline Milk SCC, $\log _{10} / \mathrm{ml}$ & $6.06^{\mathrm{a}}$ & $5.69^{\mathrm{b}}$ & $5.98^{\mathrm{a}}$ & 0.06 \\
\hline
\end{tabular}

${ }^{1}$ Data are least square means and standard error of the mean (n $=30$ ).

${ }^{2}$ Once (1X) or twice (2X) daily milking.

a,b,c Means with different superscripts within the same row are different $(P<0.05)$.

with higher SCC was produced, when compared to $2 \mathrm{X}$ cows (Holmes et al., 1992).

Overall means of milk SCC increased as lactation stage advanced $(P<0.01)$ and milk from the 4 th mo of lactation or later exceed the limit of $1 \times 10^{6}$ cells $/ \mathrm{ml}$. These results agree with the increase in SCC in goats as lactation advance (Wilson et al., 1995; Salama et al., 2003). The reason for this rise in SCC as lactation progresses may be due to both a concentration effect as less milk is produced and to the presence of chemostatic cytokines that draw polymorphonuclear leukocytes into milk in higher concentrations during late lactation (Manlongat et al., 1998). Also, SCC significantly increased $(P<0.001)$ as parity number increased (Table 2 ) as previously reported by Sánchez et al. (1999) in dairy goats. This increase could be attributed to the increased prevalence of bacteria in the mammary gland of older animals, or to the cumulative stress of the mammary tissue from several pregnancies and lactations (Boscos et al., 1996).

\section{Secretion of Milk and Its Components}

Hourly milk secretion rate had the greatest value for the 8-h milking interval and significantly decreased as time after milking increased (Table 3 ). The reduction was more marked for the 16 to 24 -h interval $(-18 \%)$ than for the 8 to 16 -h interval $(-11 \%)$ indicating a secretion rate saturation effect with time, as reported in goats (Peaker and Blatchford, 1988), dairy ewes (McKusick et al., 2002) and cows (Knight et al., 1994; Davis et al., 1998; Ayadi et al., 2003). Hourly milk secretion rates in our results were greater than those calculated from data reported ( 52 to $54 \mathrm{~g} / \mathrm{h}$ ) by McKusick et al. (2002) in dairy ewes milked every $12 \mathrm{~h}$ or every $16 \mathrm{~h}$.
Fat secretion rate was greater for the 8-h milking interval, but the values did not differ for the 16 and 24-h milking intervals (Table 3). Alveolar milk is richer in fat content than cisternal milk, which may explain the higher fat content during the 8-h period after milking as compared with 16 and $24 \mathrm{~h}$ after milking and confirms the importance of milk ejection during milking for recuperation of alveolar milk that is rich in TS (McKusick et al., 2002). However, fat percentage did not differ between 8 and $24 \mathrm{~h}$ after milking. Despite the milk yield and specie differences, hourly fat secretion rates in our results for the 16 and 24-h milking intervals were also similar to those calculated (2.7 to $2.9 \mathrm{~g} / \mathrm{h}$ ) from McKusick et al. (2002) in dairy ewes milked every 12 or $16 \mathrm{~h}$. This may be a result of the plateau observed in the transfer of fat from alveolar milk to cisternal milk during the longer milking intervals, resulting in an accumulation of fat in the alveolar compartment (McKusick et al., 2002).

Protein secretion rate was significantly greater for the $8 \mathrm{~h}$ after milking, but the value did not differ for the 16-h milking interval (Table 3 ). The lowest secretion rate of milk protein was observed at the 24-h milking interval. Hourly milk protein secretion rates in our results were smaller than the value calculated from McKusick et al. (2002) in dairy ewes milked every 12 or $16 \mathrm{~h}(2.5 \mathrm{~g} / \mathrm{h})$. Protein percentage increased as time after milking increased (Table 3), indicating a significant concentration effect in the milk accumulated in the udder after a 16- or 24-h milking interval, as discussed above. Regarding milk CN, secretion rate was decreased as milking interval increased and the concentration effect was clearer when $\mathrm{CN}$ percentage increased significantly according to time after milking (Table 3).

Milk at $8 \mathrm{~h}$ had the highest SCC (Table 3), which is consistent with reports of lower SCC in fore-stripped milk compared to stripped milk (Gonzalo et al., 1993) and milk SCC according to milking interval (McKusick et al., 2002) in dairy ewes. At $16 \mathrm{~h}$, as cisternal milk percentage increased, milk SCC significantly decreased. However, milk SCC increased at $24 \mathrm{~h}$, which may be associated with leaky TJ between mammary epithelial cells occurred after $20 \mathrm{~h}$ in dairy goats (Stelwagen et al., 1994b) facilitating the paracellular influx of somatic cells into milk (Stelwagen and Lacy-Hulbert, 1996). Therefore, if milk quality in dairy goats was based on SCC, the 16-h interval would appear to be the most appropriate interval to produce milk with high quality. Milking 3 times every $48 \mathrm{~h}$ (16-h interval between milking) may also be a better alternative to $1 \mathrm{X}$, and McKusick et al. (2002) showed that milking East Friesian ewes every $16 \mathrm{~h}$ did not affect milk yield, milk 
components, or SCC as compared with twice daily milking at an interval of $12 \mathrm{~h}$.

\section{CONCLUSIONS}

Once daily milking in Murciano-Granadina dairy goats moderately reduced milk yield without negative effects on milk composition and udder health. Since milk of $1 \mathrm{X}$ goats contained more fat without significant increases in SCC, reduced revenue due to lower milk yield could be partially offset if payment for milk was based on milk quality. Once daily milking for dairy goats in early lactation and for dairy goats of less than four parities may not be a suitable management decision because of higher losses. However, the reduction in total labor when once daily milking is adopted permits farmers more time to devote to other farming practices and/or to other activities off the farm, improving their productivity and standard of life.

\section{ACKNOWLEDGEMENTS}

This work is part of a European Commission-DG VI (Agri) research project (FAIR 1, CT95-0881) and was supported by a research scholarship to A. A. K. Salama from Agencia Española de Cooperación Internacional (AECI). The authors are also grateful to Ramon Costa and the team of the S1GCE (Servei de Granges i Camps Experimentals) of the UAB for the care of the animals and to Nic Aldam for reviewing the manuscript.

\section{REFERENCES}

Albanell, E., P. Cáceres, G. Caja, E. Molina, and A. Gargouri. 1999. Determination of fat, protein, and total solids in ovine milk by near-infrared spectroscopy. J. AOAC Int. 82:753-758.

Ayadi, M., G. Caja, X. Such, and C. H. Knight. 2003. Use of ultrasonography to estimate cistern size and milk storage at different milking intervals in the udder of dairy cows. J. Dairy Res. 70:1-7.

Bewley, J., R. W. Palmer, and D. B. Jackson-Smith. 2001. Modeling milk production and labor efficiency in modernized Wisconsin dairy herds. J. Dairy Sci. 84:705-716.

Boscos, C., A. Stefanakis, C. Alexopoulos, and F. Samartzi. 1996. Prevalence of subclinical mastitis and influence of breed, parity, stage of lactation and mammary bacteriological status on Coulter counter counts and California mastitis test in the milk of Saanen and autochthonous Greek goats. Small Ruminant Res. 21:139147.

Capote, J., J. L. López, G. Caja, S. Peris, A. Arguello, and N. Darmanin. 1999. The effects of milking once or twice daily throughout lactation on milk production of Canarian dairy goats. Pages 267273 in Milking and Milk Production of Dairy Sheep and Goats. F. Barillet and N. P. Zervas, ed. Wageningen Pers, Wageningen, Netherlands.

Cowie, A. T., and J. S. Tindal. 1971. The Physiology of Lactation. Camelot Press Ltd., London, England.

Davis, S. R., V. C. Farr, P. J. A. Copeman, V. R. Carruthers, C. H. Knight, and K. Stelwagen. 1998. Partitioning of milk accumulation between cisternal and alveolar compartments of the bovine udder: relationship to production loss during once daily milking. J. Dairy Res. 65:1-8.
Davis, S. R., V. C. Farr, and K. Stelwagen. 1999. Regulation of yield loss and milk composition during once-daily milking: a review. Livest. Prod. Sci. 59:77-94.

DePeters, E. J., N. E. Smith, and J. Acedo-Rico. 1985. Three or two times daily milking of older cows and first lactation cows for entire lactations. J. Dairy Sci. 68:123-132.

Dewhurst, R. J., and C. H. Knight. 1993. An investigation of the changes in sites of milk storage in the bovine udder over two lactation cycles. Anim. Prod. 57:379-384.

González, E., G. Caja, E. Albanell, C. Flores, A. Castro, R. Casals, X. Such, A. Bach, and C. Torre. 2002. Effects of fibrolytic enzyme supplementation for dairy goats in mid lactation. J. Dairy Sci. 80(Suppl. 1):355.(Abstr.).

Gonzalo, C., J. A. Baro, J. A. Carriedo, and F. San Primitivo. 1993. Use of the Fossomatic method to determine somatic cell counts in sheep milk. J. Dairy Sci. 76:115-119.

Grossman, M., S. M. Hartz, and W. J. Koops. 1999. Persistency of lactation yield: a novel approach. J. Dairy Sci. 82:2192-2197.

Hinckley, L. S. 1983. Somatic cell count in relation to caprine mastitis. Vet. Med. 78:1267-1271.

Holmes, C. W., G. F. Wilson, D. D. S. Mackenzie, and J. Purchas. 1992. The effects of milking once daily throughout lactation on the performance of dairy cows grazing on pasture. Proc. N.Z. Soc. Anim. Prod. 52:13-16.

Kamote, H. I., C. W. Holmes, D. D. S. Mackenzie, R. J. Holdaway, and B. W. Wickham. 1994. Effects of once daily milking in later lactation on cows with either low or high initial somatic cell count. Proc. N.Z. Soc. Anim. Prod. 54:285-287.

Kelly, A. L., S. Reid, P. Joyce, J. William, and J. Foley. 1998. Effect of decreased milking frequency of cows in late lactation on milk somatic cell count, polymorphonuclear leucocyte numbers, composition and proteolytic activity. J. Dairy Res. 65:365-373.

Knight, T. W., D. S. Atkinson, N. A. Haack, C. R. Palmer, and K. H. Rowland. 1993. Effects of suckling regime on lamb growth rates and milk yield of Dorset ewes. N.Z. J. Agric. Res. 36:215-222.

Knight, C. H., and R. J. Dewhurst. 1994. Once daily milking of dairy cows: relationship between yield loss and cisternal milk storage. J. Dairy Res. 61:441-449.

Knight, C. H., D. Hirst, and J. Dewhurst. 1994. Milk accumulation and distribution in the bovine udder during the interval between milkings. J. Dairy Res. 61:167-177.

Lacy-Hulbert, S. J., M. W. Woolford, G. D. Nicholas, C. G. Prosser, and K. Stelwagen. 1999. Effect of milking frequency and pasture intake on milk yield and composition of late lactation cows. J. Dairy Sci. 82:1232-1239.

Li, P., P. S. Rudland, D. G. Fernig, L. M. B. Finch, and C. J. Wilde. 1999. Modulation of mammary development and programmed cell death by the frequency of milk removal in lactating goats. J. Physiol. 519:885-900.

Manlongate N., T. J. Yang, L. S. Hinckley, R. B. Bendel, and H. M. Krider. 1998. Physiologic-chemoattractant-induced migration of polymorphonuclear leukocytes in milk. Clin. Diagn. Lab. Immunol. 5:375-381.

McDougall, S., and M. Voermans. 2002. Influence of estrus on somatic cell count in dairy goats. J. Dairy Sci. 85:378-383.

McKusick, B. C., D. L. Thomas, Y. M. Berger, and P.G. Marnet. 2002. Effect of milking interval on alveolar versus cisternal milk accumulation and milk production and composition in dairy ewes. J. Dairy Sci. 85:2197-2206.

Mocquot, J. C. 1978. Effets de l'omission régulière et irrégulière d'une traite sur la production laitière de la chèvre. Pages 175-201 in Proc. 2nd Int. Symp. Milking Small Ruminants, Alghero, Italy.

Negrao, J. A., P. G. Marnet, and J. Labussière. 2001. Effect of milking frequency on oxytocin release and milk production in dairy ewes. Small Ruminant Res. 39:181-187.

Papachristoforou, C., A. Roushias, and A. P. Mavrogenis. 1982. The effect of milking frequency on the milk production of Chios ewes and Damascus goats. Ann. Zootech. 31:37-46.

Peaker, M. 1980. The effect of raised intramammary pressure on mammary function in the goat in relation to the cessation of lactation. J. Physiol. (Lond.) 301:415-428. 
Peaker, M., and D. R. Blatchford. 1988. Distribution of milk in the goat mammary gland and its relation to the rate and control of milk secretion. J. Dairy Res. 55:41-48.

Peris, S., X. Such, and G. Caja. 1996. Milkability of Murciano-Granadina dairy goats. Milk partitioning and flow rate during machine milking according to parity, prolificacy and mode of suckling. J. Dairy Res. 63:1-9.

Rovai, M., X. Such, G. Caja, and J. Piedrafita. 2002. Changes in the cisternal and alveolar milk throughout lactation in dairy sheep. J. Dairy Sci. 85(Suppl. 1):4(Abstr.).

Salama, A. A. K., G. Caja, E. Albanell, X. Such, R. Casals, and J. Plaixats. 2003. Effects of dietary supplements of zinc methionine on milk production, udder health and zinc metabolism in dairy goats. J. Dairy Res. 70:9-17.

Sánchez, A., A. Contreras, and J. C. Corrales. 1999. Parity as risk factor for caprine subclinical intramammary infection. Small Ruminant Res. 31:197-201.

Stelwagen, K., S. R. Davis, V. C. Farr, S. J. Eichler, and I. Politis. 1994a. Effect of once daily milking and concurrent somatotropin on mammary tight junction permeability and yield of cows. J. Dairy Sci. 77:2974-3001.

Stelwagen, K., S. R. Davis, V. C. Farr, C. G. Prosser, and R. A. Sherlock. 1994b. Mammary epithelial cell tight junction integrity and mammary blood flow during an extended milking interval in goats. J. Dairy Sci. 77:426-432.

Stelwagen, K., I. Politis, J. H. White, B. Zavizion, C. G. Prosser, S. R. Davis, and V. C. Farr. 1994c. Effect of milking frequency and somatotropin on the activity of plasminogen activator, plasminogen, and plasmin in bovine milk. J. Dairy Sci. 77:3577-3583.

Stelwagen, K., and J. Lacy-Hulbert. 1996. Effect of milking frequency on milk somatic cell count characteristics and mammary secretory cell damage in cows. Amer. J. Vet. Res. 57:902-905.
Stelwagen, K., and C. H. Knight. 1997. Effect of unilateral once or twice daily milking of cows on milk yield and udder characteristics in early and late lactation. J. Dairy Res. 64:487-494.

Stelwagen, K., R. D. McLaren, S. A. Turner, H. A. McFadden, and C. G. Posser. 1998. No evidence for basolateral milk protein secretion in the lactating goat mammary gland. J. Dairy Sci. 80:434-437.

Sung, Y. Y., T. I. Wu, and P. H. Wang. 1999. Evaluation of milk quality of Alpine, Nubian, Saanen and Toggenburg breeds in Taiwan. Small Ruminant Res. 33:17-23.

Thomas, D. L., Y. M. Berger, and B. C. McKusick. 2000. East Friesian germplasm: Effects on milk production, lamb growth, and lamb survival. Proc. Am. Soc. Anim. Sci., 1999. Online available: www.asas.org/jas/symposia/proceedings/0908.pdf.

Wilde, C. J., A. J. Henderson, C. H. Knight, D. R. Blatchford, A Faulkner, and R. J. Vernon. 1987. Effects of long-term thricedaily milking on mammary enzyme activity, cell population and milk yield. J. Anim. Sci. 64:533-539.

Wilde, C. J., and C. H. Knight. 1990. Milk yield and mammary function in goats during and after once-daily milking. J. Dairy Res. $57: 441-447$.

Wilde, C. J., C. V. P. Addey, L. M. Boddy, and M. Peaker. 1995. Autocrine regulation of milk secretion by a protein in milk. Biochem. J. 305:51-58.

Wilson, D. J., K. N. Stewart, and P. M Sears. 1995. Effects of stage of lactation, production, parity and season on somatic cell count in infected and uninfected dairy goats. Small Ruminant Res. $16: 165-169$

Zeng, S. S., and E. N. Escobar. 1995. Effect of parity and milk production on somatic cell count, standard plate count and composition of goat milk. Small Ruminant Res. 17:269-274. 